\title{
Judicial Management:
}

The Achievements of

Chief Justice William Howard Taft

$\mathrm{S}$ hortly after William Howard Taft's death in 1931, his successor, Charles Evans Hughes, accurately observed that Taft's career "fittingly culminated in his work as Chief Justice," because the "efficient administration of justice was, after all, the dominant interest of his public life" (1).

This observation suggests an important distinction between associate justices and a chief justice. The primary task of associate justices is to decide cases and deliver opinions, whereas the work of the chief justice also includes administrative responsibilities for the judicial branch of the federal government. Taft's current obscurity strongly indicates that enduring professional reputation depends upon the former task, but not the latter. Indeed, when Felix Frankfurter praised Taft as a great "law reformer" and accorded him "a place in history...next to Oliver Ellsworth, who originally devised the judicial system," he unwittingly revealed what a very small place that is. It is, however, a very important one (2).

Chief justices are typically evaluated by how well they employ their prerogatives to administer the day-to-day functioning of the Court. They are scrutinized for their handling of small emergencies and for their ability to dispose efficiently of routinized institutional necessities like assigning opinions or moderating the Court's conferences. Measured by these standards, Taft was a highly successful chief justice. He was ruthlessly efficient, moving heaven and earth to force the Court to diminish its embarrassingly large backlog of cases. Louis D. Brandeis remarked to Felix Frankfurter that Taft, "like the Steel
Corporation, is attaining [all] time production records" (3). In the popular press it was said of Taft that "The spirit of speed and efficiency lurking in the corpulent form of an ex-President of the United States has entered the Court and broken up its old lethargy" (4).

Within the Court the dominant image of Taft was not that of a disciplinarian, but rather of a man who could dispose "of executive details...easily" and "get through them without friction" (5). "The new Chief Justice makes the work very pleasant," Oliver Wendell Holmes said. "He is always good natured and carries things along with a smile or a laugh. (It makes a devil of a difference if the C.J.'s temperament diminishes friction.) He is very open to suggestions and appreciates the labors of others. I rather think the other JJ. are as pleased as I am" (6).

Taft's genial and winning personality was particularly useful in managing the Court's potentially contentious conferences. Holmes said, "The meetings are perhaps pleasanter than I ever have known them-thanks largely to the C.J." (7). The justices also appreciated how "fairly" Taft distributed case assignments. Indeed, Harlan Fiske Stone later remarked that "there was never a Chief Justice as generous to his brethren in the assignment of cases" (8). Most importantly, Taft exercised a natural leadership within the Court.

Supervising the ongoing institutional routines of the Court in this manner has been an essential task of every chief justice since John Marshall. Like Taft, some chief justices have fulfilled these challenges more successfully than others, but all have understood and accepted 
these obligations of their office. Taft's unique accomplishment, however, is that he managed to expand the very concept of the chief justiceship so that his successors have also been judged by their responses to responsibilities not even perceptible before Taft. He transformed the role of chief justice by endowing it with a distinctive managerial outlook, one that he had acquired as chief executive of the nation.

Yet while Taft may have been, as William Allen White trenchantly put it, "innocent of politics" (9), he was always a capable administrator, determined to improve the efficient management of the executive branch. And it is this perspective that Taft brought with him into the chief justiceship. Specifically, Taft viewed the federal judiciary as a coherent branch of government to be managed, and he viewed the chief justiceship as the source of that management. This perspective was fundamentally new, and its implications were profound.
Taft's effectiveness as chief justice and his reworking of that position in its relationship to the federal judiciary and to Congress is illustrated by the way he secured passage of the Act of 14 September 1922, which, as Felix Frankfurter and James Landis noted, marked "the beginning of a new chapter in the administration of the federal courts" (10).

The act not only authorized the chief justice to assign district court judges temporarily to sit wherever in the country the needs of the docket were greatest, but it also created the Conference of Senior Circuit Judges to "advise as to...any matters in respect of which the administration of justice in the courts of the United States may be improved," and in particular to "make a comprehensive survey of the condition of business in the courts of the United States and prepare plans for assignment and transfer of judges to or from circuits or districts where the state of the docket or condition of business indicates the need therefor" (11). The act, Taft observed, introduced

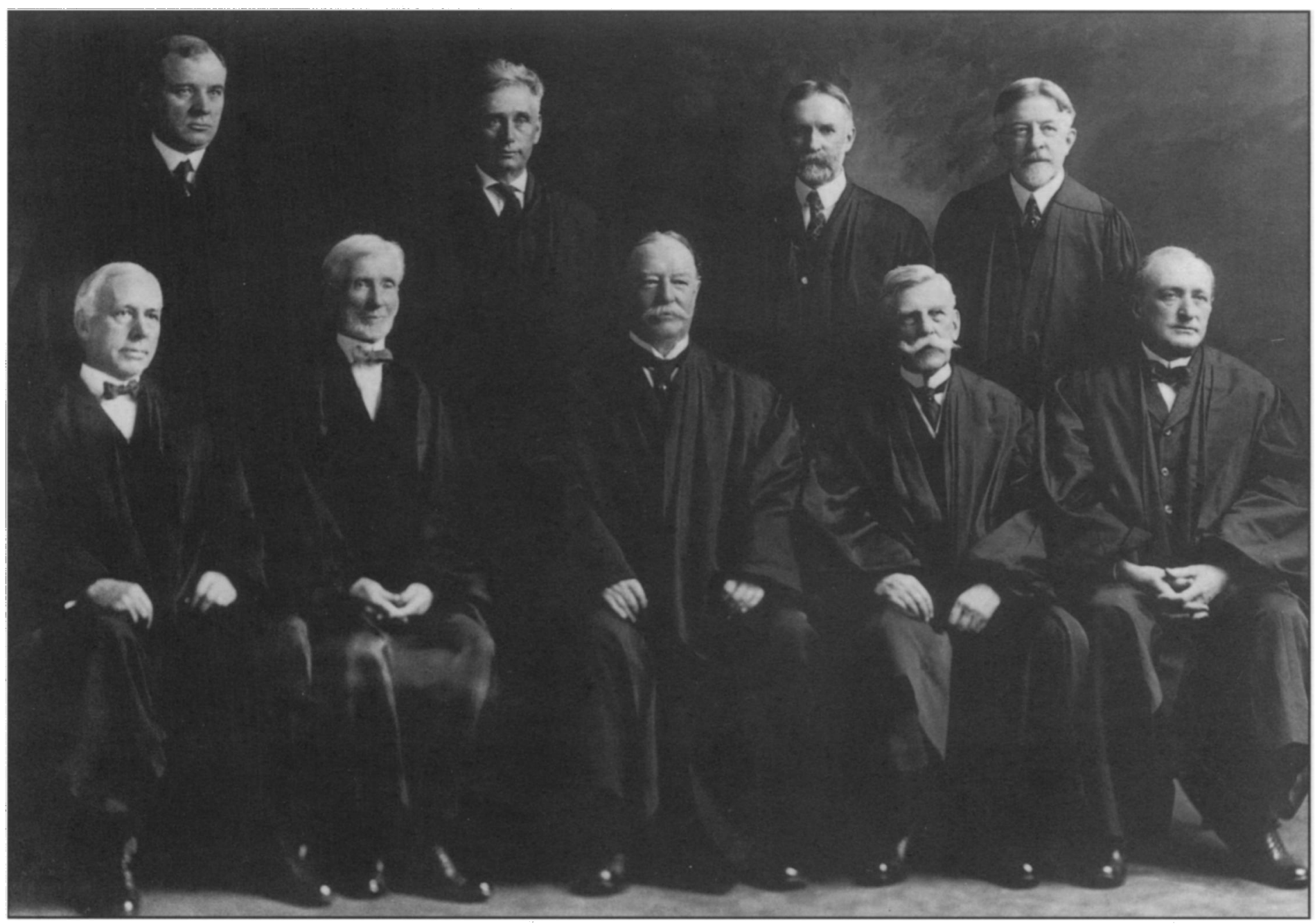

The Taft Court, circa 1923. (Courtesy of the Supreme Court of the United States, Office of the Curator.) 
"into our judicial system...an executive principle to secure effective teamwork," so that "judicial force" could be deployed "economically and at the points where most needed" (12). In Taft's view, the primary virtue of the act was to empower the chief justice and the Conference of Senior Circuit Judges "temporarily to mass the force of the judiciary where the arrears are greatest" (13).

Taft had been advocating a reform like this for years, and there was little doubt among contemporaries that the ultimate shape of the statute, as well as its enactment, were "largely the result" of his "active advocacy" (14). Taft lobbied hard for the bill, effectively mobilizing his numerous contacts within Congress, and he rightly received the lion's share of the credit for the results.

Four aspects of the Act of 14 September 1922 require emphasis: 1) the unification of the United States judiciary, 2) the management of the judicial branch, 3 ) the establishment of the tools needed for this management, and 4) the articulation of the judiciary's needs to the legislative branch. Each embodies an outlook on the federal judicial branch that reflects the influence of Taft's experience as president.

\section{Unification of the Judiciary}

First, and most fundamentally, the act implied "a functional unification of the United States judiciary" (15). Just as the executive branch has always been seen as an integrated whole, directed by the president, the act for the first time conceptualized federal judges as also integrated into a single, coherent branch of the federal government designed to attain functional objectives. Previously, as Frankfurter observed, "federal judges throughout the country were entirely autonomous, little independent sovereigns. Every judge had his own little principality. He was the boss within his district, and his district was his only concern" (16). The act, in contrast, "organized" the "whole judicial force...as a unit, with authority to send expeditions to spots needing aid" (17).

This idea may seem obvious to us today, but in 1921 it provoked great resistance. Noless a judge than Henry D. Clayton (after whom the Clayton Act was named) attacked the act as manifesting "a dictatorial power over the courts unrecognized in our jurisprudence" (18). Clayton objected to "the war idea of mobilizing judges under a supreme commander as soldiers are massed and ordered." He argued that "judges are not soldiers but servants, and the people only are the masters whom they serve" (19).

To protests like these, Taft responded with the brutal and implacable language of instrumental rationality. Although he conceded that "in the judicial work a judge does on the bench, he must be independent," Taft insisted that "in the disposition of his time and the cases he is to hear, he should be subject to a judicial council that makes him a cog in the machine and makes him work with all the others to dispose of the business which courts are organized to do" (20). The premise that judges are "organized" to accomplish a collective function renders the federal judiciary structurally parallel to an executive agency, which operates under similar logic.

\section{Management of the Judicial Branch}

Second, if judges are "cogs in a machine," there must also exist some intelligence that directs the machine. Organizations require guidance, and the functional unification of the judiciary thus implied that the judicial branch be subject to "the executive management" of "a head charged with the responsibility of the use of the judicial force at places and under conditions where judicial force is needed" (21). In this way the act transformed the federal judiciary from an "entirely headless and decentralized" (22) institution into one capable of "executive supervision" (23).

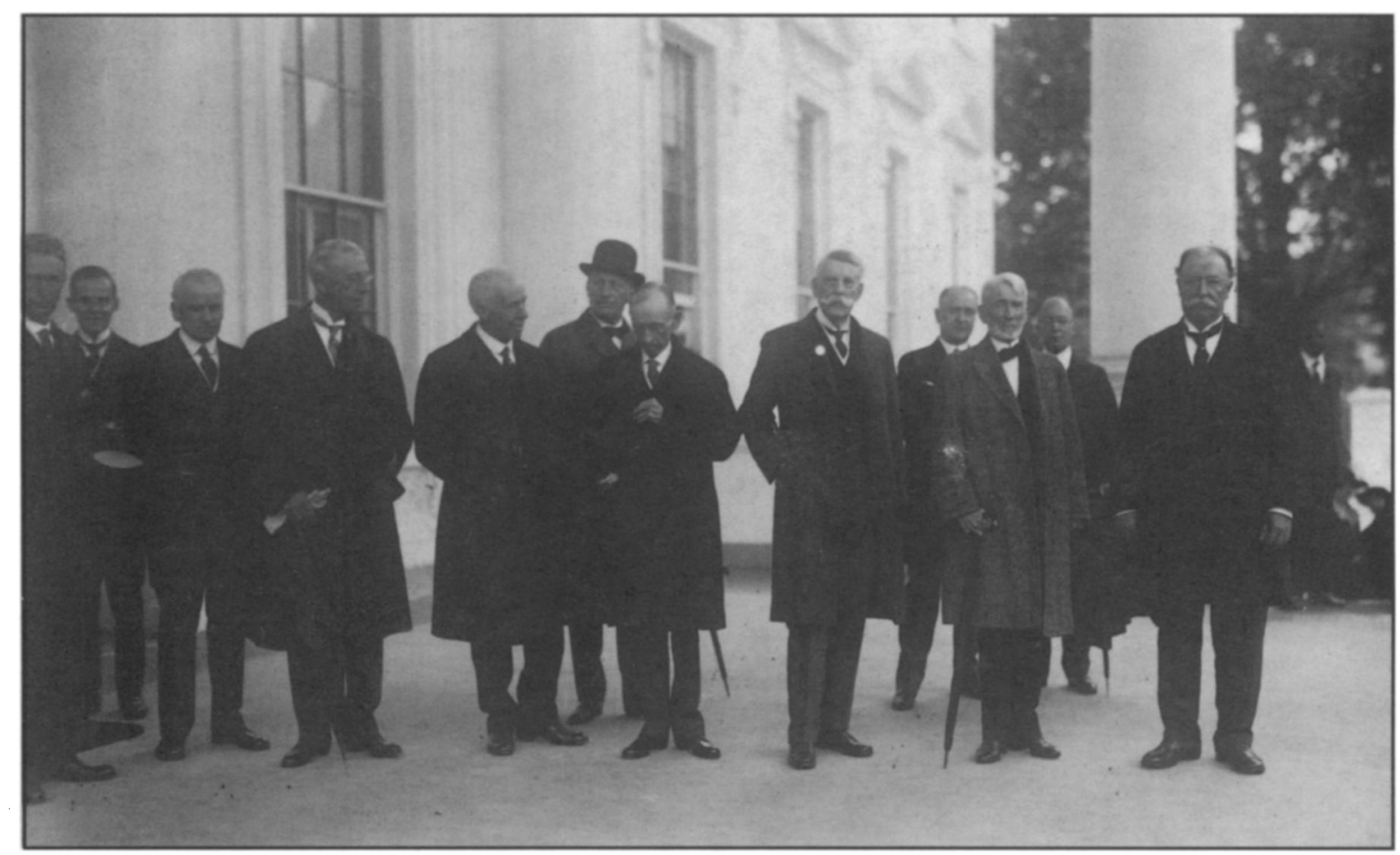

The Taft Court visits the White House, circa 1921-22. (Courtesy of the Library of Congress, 39567. ) 
Taft defended this transformation as merely a matter of "introducing into the administration of justice the ordinary business principles in successful executive work" (24). He argued that the massive increase in federal litigation required that "we must approach the problems of its disposition in the same way that the head of a great industrial establishment approaches the question of the manufacture of the amount that he will need, to meet the demand for the goods which he makes" (25). But in fact, the necessity of executive supervision was also central to Taft's conception of the president as ultimately responsible for the "administrative control" of the executive branch. In Taft's mind the chief justice, using the Conference of Senior Circuit Judges as a kind of cabinet, was responsible for the management of the judicial branch, just as the president was responsible for the management of the executive branch.

The managerial obligations that Taft imported into the office of chief justice were not exhausted by the operation of the conference. Taft enthusiastically embraced a sense of generic responsibility for the overall functioning of the federal judiciary. The letters Taft wrote to judges who had failed to decide submitted cases for unconscionably long periods of time show this responsibility:

I write in the interest of the administration of justice, and for the reputation of the Federal Judiciary, that you dispose of the patent case, which you now must have had at hand and submitted to you for more than four years....I write this letter with no assumption that I may exercise direct authority over you in the discharge of your duties, but as the head of the Federal Judiciary I feel that I do have the right to appeal to you, in its interest and in the interest of the public whom it is created to serve, to end this indefensible situation (26).

To forthrightly accept managerial responsibility in this way is not merely to seize the potential of executive supervision, but also to create lines of accountability.

\section{Establishing the Tools of Management}

Third, Taft knew that the management of the judicial branch would require the exercise of the deeply human virtues of leadership, inspiration, and a commitment to what Taft repeatedly called "teamwork, uniformity in action and an interest by all the judges in the work of each district" (27). Taft viewed the Conference of Senior Circuit Judges as a means for serving these various management functions. The conference "is a good thing," said Taft, because it "solidifies the Federal Judiciary" and "brings all the district judges within a mild disciplinary circle, and makes them feel that they are under real observation by the other judges and the country" (28). The conference was also a method of gathering information about the federal judiciary, of collecting both statistical and narrative data. And the conference was a tool for "trying to come in touch with the Federal Judges of the country, so that we may feel more allegiance to a team and do more teamwork." The conference could generate the "esprit" that came from close coordination (29).

\section{Taft freely admitted that becoming chief justice was "the ambition of my life."}

The conference, however, was only one tool for exercising executive leadership. In fact, Taft seized the opportunity for such leadership in all his dealings with federal judges. He was always "glad to keep in touch with the District Judges," because "they are the wheel horses of our system, and I want them to know that they have the deepest sympathy in their efforts in the dispatch of business" (30). He would write to a senior circuit judge requesting "a long gossipy letter so that I may acquire intimate knowledge of the situation" (31). District judges throughout the nation deeply appreciated this attention and care, and they wrote to Taft expressing their pleasure. Learned Hand, for example, said to Taft that "It is a great comfort to know the interest that you take. To be frank, we have never felt it before your incumbency" (32). As a good executive, Taft wished "to have all the members of the Federal Judiciary realize that we are remanded to the top, and that whatever we can do here in Washington to help, we will do" (33).

\section{Articulation of the Judiciary's Needs}

Fourth, as a corollary of the functional unification of the federal judiciary, the judicial branch could now articulate its ongoing and routinized requirements to the legislature, just as did the executive branch. The conference was the perfect institutional vehicle for this articulation, and Taft conceived it as enabling "the judiciary to express itself in respect of certain subjects in such a way as to be helpful to Congress" (34). Taft rapidly and effectively molded the conference into a voice for the institutional needs of the judicial branch. As he reported to the conference in 1925: "The recommendations of this Conference have a good deal of influence. I mean that they are accepted as matters for serious consideration" (35).

Taft was unwilling, however, to regard the conference as the exclusive voice of the judiciary. He believed quite strongly that the chief justice was the primary national spokesperson for the cause of the administration of justice, and he therefore sought to maintain an active personal presence in Congress in matters that transcended the pronouncements of the conference. In this regard Taft functioned as 


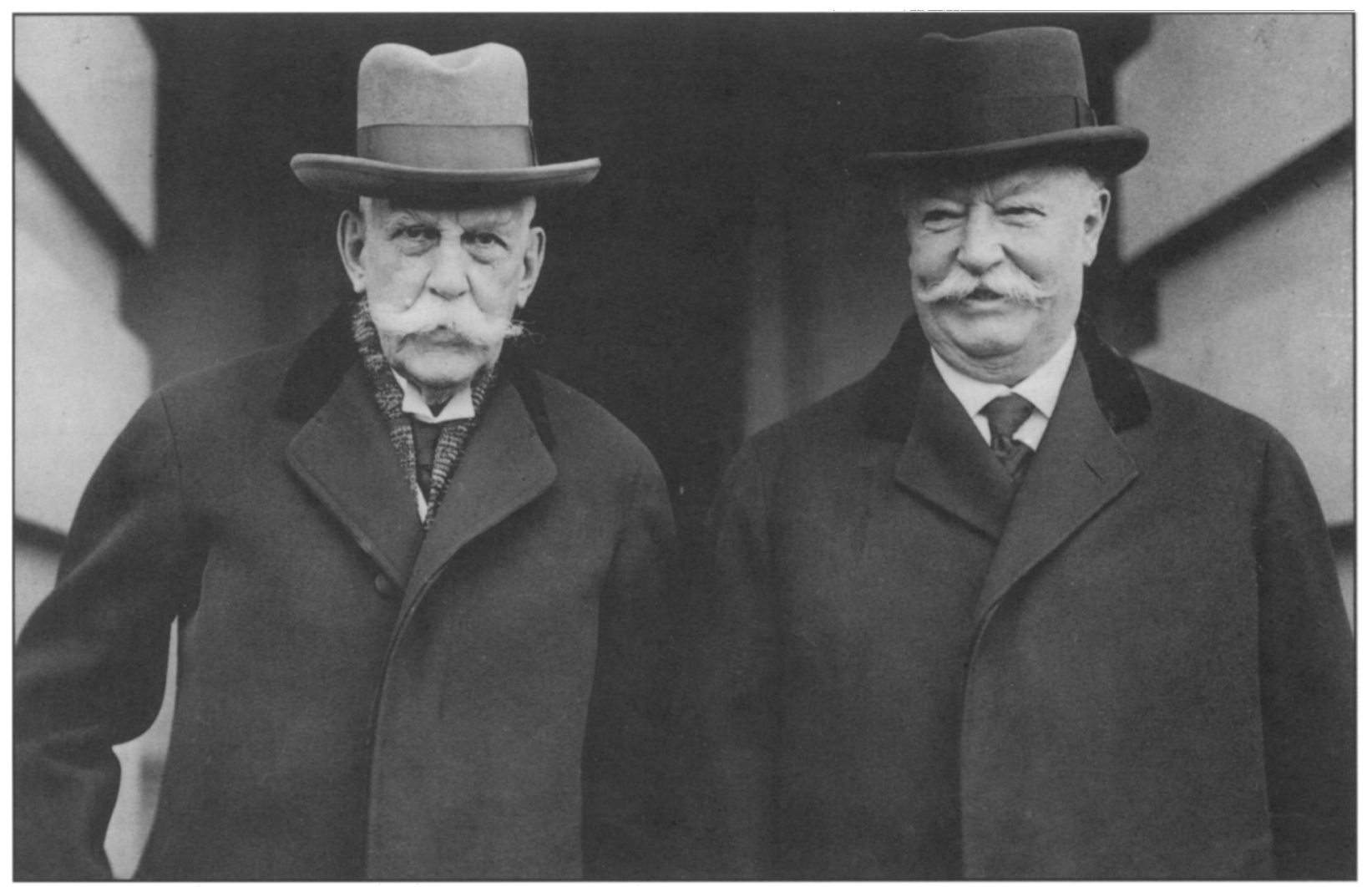

Oliver Wendell Holmes and William Howard Taft. (Courtesy of the Library of Congress, US Z62-17871.)

the certiorari jurisdiction of the Supreme Court and to reform the compensation of the Court reporter, Taft comf o r t a b l y remarked, "I hate to be in the attitude of a continual beggar from Congress, but I seem to have arrived at the court just when it was necessary" (40).

Taft did not hesitate to draft his colleagues on the Court to assist in his lobbying efforts. In 1926, for example, he brought Justices Holmes and Brandeis with him to make the

an independent lobbyist for a legislative agenda, much as he would have as chief executive.

From the very outset of his chief justiceship, Taft "thought that it was part of my duty" as the head of the federal judiciary, "to suggest needed reforms, and to become rather active in pressing them before" Congress (36). Taft was quite aware that this was a new conception of his office. "I don't think the former chief justice had so much to do in the matter of legislation as I have," he wrote to his brother Horace, but "I don't object to it, because I think Chief Justices ought to take part in that" (37).

Throughout his service on the Court, Taft was a frequent witness before Congressional committees, lobbying hard for judicial reforms. His relentless determination "to keep pressing" Congress for legislation began almost immediately after he assumed office (38). On 5 October 1921, he testified before the Senate Judiciary Committee in support of the bill that became the Act of 14 September 1922 . He realized that he had "violated the precedent in doing this," but he was unfazed, because "I am determined to exercise such influence as I have to help the judicial system of the country. Precedents that keep the judges away from committees who are to help are not precedents that appeal to me" (39). By 30 March 1922, in the course of testifying before the House Judiciary Committee in favor of bills to enlarge case before a subcommittee of the House Appropriations Committee for a deficiency appropriation to enable the First Circuit to purchase an urgently needed bar library. "I wanted to bring some big guns to bear," Taft explained. "I am a constant visitor and I did not consider that I had influence enough. This is a real emergency" (41). It was said of Taft that the chief justiceship was his "manifest destiny" (42). Certainly he freely admitted that the office was "the ambition of my life" (43). When Taft finally attained that ambition, it was after a long career of executive administration: as governor of the Philippines, Secretary of War, and President of the United States. Taft brought this experience with him as he appropriated the role of chief justice and made it his own. It was natural for him to regard the administrative duties of the chief justiceship as analogous to the executive responsibilities with which he was so familiar, especially because there were powerful English precedents for this approach to judicial administration.

\section{Conclusion}

The most lasting effect of Taft's unique perspective was its root assumption that the federal judiciary was not a collection of independent judges, but instead a unified branch of government with functional obligations. No chief justice after Taft has escaped being 
evaluated on his attention to these obligations. In this regard, Taft did indeed transform the office of chief justice.

But Taft, flush with the enthusiasm of a new idea and filled with the contacts and self-assurance of an admired ex-president, pushed this perspective to its natural limits. The difficulty he encountered, but clearly did not fully conceptualize, was that executive administration in the context of a regime of separation of powers contains important elements that are essentially political, and that therefore stand in tension with American ideals of judicial nonpartisanship and to the American institution of judicial review. Taft struggled with this tension throughout his tenure as chief justice, acting in ways that fell on different sides of what today might be regarded as obvious ethical boundaries.

Taft truly deserves to be known as the father of federal judicial management. We can learn from his difficulties, however, how subtle and complex is the relationship between the imperatives of judicial management and American norms of proper judicial behavior. Chief justices after Taft can no longer share his naive Progressive faith in the neutrality of disinterested administration. In our own fallen world of post-Progressive disillusion, chief justices must somehow negotiate between the necessities of functional rationality and the requirements of judicial neutrality. If Taft can teach us anything, it is that this negotiation will be neither clear nor easy. $\square$

\section{Endnotes}

1. "Taft's Life Praised as Truly American," New York Times, 9 March 1930, 1.

2. Felix Frankfurter, "Chief Justices I Have Known," in Felix Frankfurter on the Supreme Court (Cambridge: Belknap Press of Harvard University Press, 1970), 487-88.

3. Brandeis to Felix Frankfurter, 6 March 1925, in "HalfBrother, Half Son:" The Letters of Louis D. Brandeis to Felix Frankfurter, ed. Melvin I. Urofsky and David W. Levy (Norman: University of Oklahoma Press, 1991).

4. Herbert Little, "The Omnipotent Nine," The American Mercury 15, no. 57 (September 1928): 48.

5. Oliver Wendell Holmes to Sir Frederick Pollock, 2 October 1921, in Holmes-Pollock Letters: The Correspondence of Mr. Justice Holmes and Sir Frederick Pollock 1874-1932, ed. Mark DeWolfe Howe (Cambridge: Harvard University Press, 1941), 79.

6. Holmes to Baroness Charlotte Moncheur, 2 June 1922, Holmes Papers, reel 26, frame 761 .

7. Holmes to Pollock, 24 February 1923, Holmes-Pollock Letters, ed. Howe, 113-14.

8. Stone to Thomas Reed Powell, 30 January 1940, Stone Papers.

9. William Allen White, Masks in a Pageant (New York: MacMillan, 1928).

I $\rightarrow$ Felix Frankfurter and James M. Landis, "The Business of the Supreme Court of the United States-A Study in the Federal Judicial System-Part IV: The Conference of Senior Circuit Judges," Harvard Law Review 40 (1927): 431, 456.

11. Ibid., 431, 444.
12. William Howard Taft, "Adequate Machinery for Judicial Business," American Bar Association Journal 7 (1921): 453-54.

13. Taft to Charles D. Hillis, 5 February 1923, Taft Papers, reel 250.

14. "Unification of the Judiciary: A Record of Progress," Texas Law Review 2 (1924): 445, 452-53.

15. "Rally Support for Daugherty Bill: Bar of Entire Country Asked to Lend Assistance in Campaign for Effective Organization of United States Judiciary," Journal of the American Judicature Society 5 (1921): 120.

16. Frankfurter, "Chief Justices I Have Known," 487-88.

17. "The First Conference," $A B A J 9$ (1923): 7.

18. Henry D. Clayton, "Popularizing Administration of Justice," $A B A J 8$ (1922): 43, 46, quoting Judge Sheppard.

19. Ibid.

20. Taft to E. Cockrell, 5 May 1927, Taft Papers, reel 291.

21. William Howard Taft, "The Attacks on the Courts and Legal Procedure," Kentucky Law Journal 5 (1916): 3, 16-17.

22. "Unification of the Judiciary," 445.

23. William Howard Taft, "The Courts and the Progressive Party," Saturday Evening Post 186, no. 39 (20 March 1914): 47.

24. Taft, "The Attacks on the Courts," 3, 16.

25. William Howard Taft, "Address of the President," American Bar Association Report39(1914): 359, 383.

26. Taft to John A. Peters, 11 October 1927, Taft Papers, reel 295.

27. Taft to John F. Sater, 27 August 1921, Taft Papers, reel 233.

28. Taft to Robert Taft, 2 October 1927, Taft Papers, reel 295.

29. Taft to Frank S. Dietrich, 17 January 1927, Taft Papers, reel 288.

30. Taft to John S. Partridge, 22 January 1925, Taft Papers, reel 271.

31. Taft to William B. Gilbert, 15 December 1924, Taft Papers, reel 270.

32. Leonard Hand to Taft, 1 March 1923, Taft Papers, reel 251.

33. Taft to Dietrich, 17 January 1927.

34. Taft to Robert Taft, 2 October 1927.

35. Report of the Fourth Conference of Senior Circuit Judges called by the Chief Justice pursuant to the Act of Congress of 14 September 1922, 38, Taft Papers, reel 618.

36. Taft to Frank H. Hiscock, 12 April 1922, Taft Papers, reel 241. 37. Taft to Horace Taft, 30 March 1922, Taft Papers, reel 240.

38. Taft to Charles M. Hepburn, 10 April 1923, Taft Papers, reel 252. 39. Taft to Horace Taft, 6 October 1921, Taft Papers, reel 234.

40. House Committee on the Judiciary, Hearing on H.R. 10479, $67^{\text {th }}$ Cong., $2^{\text {nd }}$ Sess., 30 March 1922, 10.

41. Subcommittee on Appropriations in Charge of Deficiency Appropriations, Hearing on the Second Deficiency Appropriations Bill, $69^{\text {th }}$ Cong., $1^{\text {st }}$ Sess., 13 May 1926, 766.

42. Ernest Knaebel to Taft, 1 July 1921, Taft Papers, reel 228.

43. "Taft Awed by Gaining Goal of His Ambition," New York Herald (1 July 1921): 2.

Robert Postis the Alexander F. and MayT. Morrison ProfessorofLawatthe University of California at Berkeley and is the author of Constitutional Domains: Democracy, Community, Management (1995). 